\title{
THE PREMATURE ENDS OF CENTRAL EUROPE
}

\section{WERONIKA PARFIANOWICZ-VERTUN, EUROPA ŚRODKOWA W TEKSTACH I DZIALANIACH. POLSKIE I CZESKIE DYSKUSJE}

Karolina Ćwiek-Rogalska

Polish Academy of Sciences, Warsaw

In the last dozen or so years, it has been thought proper to advance and defend the thesis that there is no such thing as "Central Europe." This once widespread term was considered blurry and overused. Dragged through muck and mire, Central Europe was supposed to be a utopia, often attributed to a single, equally mysterious, social class - the intelligentsia. "Central Europe" was imagined to be a fantasy, an unfulfilled dream, and even an attempt to fake history. In her book Europa Środkowa w tekstach $i$ działaniach [Central Europe in Texts and Actions] (2016), Weronika Parfianowicz-Vertun points to the critical potential of the term. What moved intellectuals to theorise the existence of Central Europe during communist times was the opportunity to build the identity of opposition circles around this notion. Parfianowicz-Vertun writes that "Central Europe can be defined as a region in which dissenters' actions led to the creation of relatively permanent, independent culture cycles" (Parfianowicz-Vertun 2016: 13-14). ${ }^{1}$ The author is trying to distance herself from any speculation about where Central Europe actually is - a problem so far unresolved and most probably insoluble. We are dealing here with something that, as the author suggests, manifests itself through discourse rather than through any

1 All translations of cited fragments are my own. 
political project. Here Parfianowicz-Vertun differs from thinkers who saw "Central Europe" as a useful concept of a new geopolitical order (ibid.: 14).

The subject matter of Weronika Parfianowicz-Vertun's book is the debate about Central Europe in Czech $^{2}$ and Polish opposition circles in the 1970s and 1980s. This does not mean, however, that the author limits herself to that bit of historical reality: she refers to the debate's genesis and its aftermath, as well as considering its resonance in Hungary.

Europa Środkowa w tekstach $i$ diqiałaniach consists of four chapters. In the first, Parfianowicz-Vertun discusses problems with defining Central Europe, how it is represented in essays, and her own method of exploring this idea as a social concept. In chapter 2, she shows how Central Europe was created in texts and how those texts were written. Thus the symbolic reality of texts is embedded in the practical conditions of the intellectual's métier. Parfianowicz-Vertun points to certain cultural and social aspects of opposition life in Poland and in Czechoslovakia, such as gender inequality with respect to participation and recognition, or close links between the opposition and alternative culture. In chapter 3 she discusses the abovementioned questions in the Czech context, focusing on three selected essays by Czech authors: Karel Kosík, Václav Bělohradský, and Josef Kroutvor. She also points to the fact that the concept of "Central Europe" is entangled in the debate over the so-called "Czech question,"3. the Czech National Revival, ${ }^{4}$ and political tensions between nationalism, capitalism, and modernisation. The last, fourth, chapter is devoted to Polish visions of Central Europe; Parfianowicz-Vertun concentrates on emigrant intellectuals grouped around the journal Kultura. She also points to how Polish ideas

\footnotetext{
${ }^{2}$ Thus, as the author proposes, in this article I use the word "Czech" rather than "Czechoslovak," because the issues discussed concern Czech culture. What was happening in Slovakia was not included in the book (Parfianowicz-Vertun 2016: 86). However, when I refer to the country in which the phenomena took place between the years 1945 and 1992, I use the name "Czechoslovakia."

${ }^{3}$ Essentially, the "Czech question" is a group of issues consisting of several ways of asking: (a) ontologically - who are we as Czechs, and what does it mean to "be Czech"?; (b) politically - what is the Czech raison d'état?; (c) morally - how should one be a Czech?; and (d) esthetically - what kind of an experience is "being Czech"? In some of these points, the "Czech question" is therefore directly connected with the discussion about the meaning of Czech history.

${ }^{4}$ The so-called national revivals took place throughout the Slavic cultures (as well as outside, see Hobsbawm \& Ranger 2008), apart from the Polish and Russian lands, where relative cultural continuity has been preserved. In the case of the Czech lands, this process was meant to fill the cultural gap that came into existence after 1620, when, as a result of repression, most of the upper classes either emigrated or were executed or germanised, thus stopping the development of Czech culture, and above all of the language, which survived mostly in the villages. At the end of the eighteenth century the process of reconstructing and redesigning Czech identity started and was called the "National Revival." The intellectuals - the academics, artists, social activists, and politicians - who took part in it are called "revivalists" (Czech: buditelé).
} 
of Central Europe were linked to a vision of the role of Poland's pre-war territories, the so-called "Kresy" [Borderlands]. If Europa Srodkowa w tekstach $i$ driataniach were to be placed on the map of the contemporary humanities, it would lie on the borderland between the history of ideas, studies of material culture, and textual anthropology.

As a scholar in the field of Czech studies, I will focus on the Czech side of the debate analysed by Parfianowicz-Vertun. Incidentally, this review strategy is encouraged by the book itself, as the author invites a reading that keeps the Czech and the Polish debates apart. Parfianowicz-Vertun shows that the Polish and Czech visions have little in common, as in each case "Central Europe" is viewed from a different perspective.

\section{/// Who Creates Central Europe?}

Parfianowicz-Vertun's aim is not, as she herself stresses, to propose a clearcut definition of Central Europe, delineating its geographic, historical, and cultural boundaries (2016: 16). Instead, the author wonders why the concept of Central Europe continues to return, despite severe criticism, and what functions it has performed in respective decades and environments in countries such as Czechoslovakia (later the Czech Republic), Poland, and Hungary, and in the West. Parfianowicz-Vertun bases her claims on an analysis of 1970s and 1980s Polish and Czech samizdat press (ibid.: 71), justifying the choice of research materials by the fact that debates were at the time intense and connections between Polish and Czech opposition members strong and numerous (ibid.: 16). She tries to overcome the paradigmatic dilemma of geography, proposing to redefine Central Europe as a social concept along the lines of Ludwik Krzywicki's formulation. Thus Central Europe becomes a task - an ideal that people need to have in order to imagine ways to achieve it (ibid.: 19). At the same time, as she writes, Central Europe is a travelling concept ("crossing borders and developing in parallel in different environments and adapting to different forms depending on the social, historical, and political context," ibid.: 19) which is also "practised" "“from which sprung various activities and undertakings," ibid.: 19). Her understanding of a "travelling concept" has little to do with Mieke Bal's (Bal 2002). Rather than broaden the discussion in the history and cultural theory of ideas, Parfianowicz-Vertun's travelling concepts simply mirror her conceptualisation of a Central Europe that is "not an autonomous, permanent, pre-established value but is updated and can be 
captured only in relation to those who call on it, express it, or practise it" (Parfianowicz-Vertun 2016: 19).

Who are "they"? Parfianowicz-Vertun points to the origin of the notion of "Central Europe." It was initially meant to be "the idea of several intellectuals," (Parfianowicz-Vertun 2016: 19, 368) or even "a republic of friends" (ibid.: 189). Any scholar familiar with the Czech context knows this old joke: the Czech nation would probably never have been born, and the Czech National Revival would have ended in a flash, if the roof over the Revivalists' favourite café had collapsed. Of course, the anecdote makes us aware of how few they were, but it is also a starting point for me to ask how strongly the idea of "Central Europe," as Parfianowicz-Vertun describes it, is connected to the idea of the Czech National Revival. Since the author considers the question of what was said about Central Europe to be more important than what Central Europe was (or has been), it is absolutely justified to wonder how large the circle was that discussed the subject (ibid.: 21).

Parfianowicz-Vertun is interested in "practices through which the idea of Central Europe is heard, the content of individual projects, and finally - their reception" (2016: 21). The way these projects looked depended on the context in which they were created. Parfianowicz-Vertun is therefore thinking about "ways of creating and circulating texts, techniques of their reproduction, writing and reading practices" (ibid.: 22), and often also about social activities that have so far gone unnoticed (ibid.: 25). This context also implies ad hoc responses to the situation: various projects of Central Europe were responses to the problems people confronted at the time (ibid.: 24).

Whether the reader agrees with the author's findings depends on a variety of factors: first, on the choice of key figures in the Czech part of the book. Parfianowicz-Vertun analyses three essays by three intellectuals whose perspectives differed but at the same time were closely related to the cold war reality. Josef Kroutvor's project of Central Europe was a reaction to the events of 1968 and was designed from the perspective of an emigrant; Václav Bělohradský defined Central European problems from the more comfortable perspective of a scholar at a Western university; and Karel Kosík, a Marxist-revisionist, who stayed in Czechoslovakia, focused on the future, trying to draft future trajectories for the Czechs after 1968.

Parfianowicz-Vertun is certainly right in focusing on intellectuals: after all, the debate over Central Europe mainly engaged this social stratum. However, the discussions of the 1970s and 1980s marked a revival of the "Czech question" (Czech: česká otárka) and invited inquiries into the 
meaning of Czech history (Czech: smysl reskeých dějin). Parfianowicz-Vertun devotes little attention to this context. Thus she fails to account for the debate over Central Europe as an intellectual tradition.

Miloš Havelka, a historian and political scientist, convincingly argues that it was Jan Patočka, one of the most eminent Czech philosophers of the twentieth century, who reopened the old discussion with his reinterpretations of Tomáš Garrigue Masaryk's writings. Patočka's theses and questions underlie the Czech debate on Central Europe in the period studied by Parfianowicz-Vertun, thus giving evidence of the durability of the main dilemmas connected to this political project (Havelka 2001: 103). Parfianowicz-Vertun notes Patočka's influence (2016: 218) but does not reflect on it as a fact in the history of ideas. However, the specificity of this Czech discussion lies in its high autotelity with regard to its "founding father." It is indeed a chain of reinterpretations of the earlier texts on the subject, ${ }^{5}$ each more or less directly evoking the theses of the "father of Czech history," František Palacký. As Jan Patočka remarked, all this discussion could be considered as, to use Whitehead's expression, "a series of footnotes" to Palacký.

Narrowing her analysis down to only three essays, Parfianowicz-Vertun cannot grasp the dynamics of the debate: the shifting positions and constant revisions of earlier opinions by its main participants. For example, Kosík, in his text referring to Masaryk's work "Naše nynější krize" [Our Current Crisis] put forward a thesis that is the opposite to the main claim in the essay analysed by Parfianowicz-Vertun, "Co je Střední Evropa?" [What is Central Europe?]. Bearing in mind that both essays appeared in one volume, Století Markety Samsové [The Century of Gerta Samsa] after the Velvet Revolution, it is a pity that this shift of opinion passes unnoticed. While analysing Kosík's latter essay, Parfianowicz-Vertun writes that "in this construction there is no question about the condition of society, the responsibility of the individual towards himself, his community, or others - about the possibility of action and the consequences of its lack" (2016: 218). Let us, however, remember that in "Naše nynější krize," Kosík, who was interested above all in human existence as a moral task, writes that

[a nation] is a nation for as long as it is something more than just an existence. Mere existence cannot be a programme for, and the meaning of, the nation. Where existence is everything, the nation

${ }^{5}$ Naše dvě otázky by Hubert Gordon Schauer (1886) and Ceská otázka by Tomáš Garrigue Masaryk (1895). 
becomes nothing, i.e., it is a biological being or a random historical creation. The nation defends its existence, but it is always about the meaning of this existence. Palacký’s "božnost," Havlíček's “poctivost," Masaryk's "bumanita" are a historical response to the question of the meaning of human existence, on the basis of which the role of the Czech nation is studied (Kosík 1993: 37). ${ }^{6}$

However, capturing these differences in the philosopher's thoughts becomes possible only when one grasps them in the perspective of a longer duration. Kosík himself mentions not only Masaryk, to whom he refers in the title of the essay, but also two ideological protoplasts of the Czech parties dominating the political scene until the end of the nineteenth century: Palacký (the Old Czech Party) and Karel Havlíček Borovský (the Young Czech Party).

Havelka pointed to yet other problems with regard to Kosík's essays:

After Karel Kosík's pioneering - albeit in some respects problematic - work O pojmu Stredni Evropy published in 1969, and indeed from his reflections in the first half of the 1960s on the meeting between Josef K. and Josef Švejk on Neruda Street near Hradčany, the subject of Central Europe on the Czech scene mainly and repetitively attracted propagators of mostly conservative and often unilateral cultural criticism of national history and the Czech present, or at best those who tried to emphasise the moments of independent cultural identity - the mental difference with the East in particular, the political specificity and historical continuity of this space. Historically and politically weak, Czech conservatism unexpectedly encountered Great Hungarian conservatism, whose cultural epitome, for example, is ... the book Requiem pour un empire défunt: Histoire de la destruction de l'Autriche-Hongrie by HungarianFrench historian Francoise Fejtö (Havelka 2001: 19-20).

The paradoxical character of independent culture in Poland and in Czechoslovakia is noted by Parfianowicz-Vertun when she writes that it was at the same time conservative, with its back turned to the past, reviving old entities - all of which inevitably influenced the concepts of Central Europe that she analyses (2016: 162). However, it might be asked whether

${ }^{6}$ I quote the texts of Czech authors in my own translation. 
these tensions were not a correlate of the autotelic nature of the debate on Central Europe: the constant search for the historical and ideological roots of the concept. Such an assumption would once again make it necessary to look closer at the relationship between the idea of Central Europe and the Czech National Revival.

Perhaps one way to understand the opposing ideas put forward in the essays analysed is to be found in Parfianowicz-Vertun's book - in her interpretation of the meaning of the literary form in which projects of Central Europe were formulated. Understanding the essay as "a kind of intellectual and writing practice" (2016: 33-34) explains, Parfianowicz-Vertun claims, the winding path of ideas taken by the leading debaters. She refers here to Andrzej Stanisław Kowalczyk's remarks on the genre (1990): "the essay is a literary expression of the cultural crisis; it appears most often in transitional periods and disappears when new attitudes, conventions, and expressions are universally accepted and established" (ParfianowiczVertun 2016: 36). The idea of Central Europe is revived especially in times of crisis, as Parfianowicz-Vertun writes (ibid.: 37). The claim holds water and even seems inspiring in the case of the Czech National Revival and the debates over the meaning of Czech history and the "Czech question." Nevertheless, the term "crisis" hardly fits the normalisation period, which is precisely the era analysed by the author: the 1970s and 1980s in Czechoslovakia. Generalised claims about the genre and its favourable climate fail to account for actual history - and the case is similar for the tempting proposition that "to read one text about Central Europe is to read them all" (ibid.: 15), which seems to be a metaphysical claim about the Central European Geist rather than a useful research tool.

\section{/// The Czech Knot}

Parfianowicz-Vertun advances the thesis that the history of the concept of "Central Europe" and its discussion is "a history of the shift of political, geopolitical, and historical discourses towards cultural issues" (2016: 23). And yet she decides to emphasise the link between the so-called "Czech question," the dispute over the meaning of Czech history, and the idea of Central Europe - which calls into question the aforementioned claim. What shifts are we dealing with here? The "Czech question" is inherently political, just as Tomáš Garrigue Masaryk famously formulated it. In his 
writings, "political" meant the same as "cultural" in Aristotle's work.7 "Political" was therefore "civic," and "public," referring to the whole of society. Masaryk himself, in writing about the crisis of the Czech community, stated that every political movement in this situation must also be a cultural formation (Masaryk 1948 [1895]: 236).

Parfianowicz-Vertun does not renounce the connection between these three discourses: Central Europe, the "Czech question," and the dispute over the sense of Czech history. Many of her reflections fall within the scope of what has been going on through all stages of the discussion over the meaning of Czech history: for example, the role of the East and West in connection with the concept of Central Europe, which corresponds to the idea of the Czech lands - or Slavic lands as such - already expressed by Palacký as a bridge between the two spectres of European culture (Palacký 1900: 379). The meeting of the East and West has strengthened the local culture by providing inspiration and impulses for further development. In the context of the second half of the twentieth century, as ParfianowiczVertun points out, it often had a purely practical dimension:

It was not always important to say something new about Central Europe, but to be involved - through speaking or writing about it - in a community, to show activity, to express views and selfidentification. Speaking and writing about Central Europe in the 1970 s and 1980s also meant keeping abreast of the latest intellectual trends, increasing the chances of being published in a prestigious journal or of getting a scholarship at a Western university (Parfianowicz-Vertun 2016: 60).

The "foggy idea" of Central Europe was clearly also a springboard to a career.

However, Parfianowicz-Vertun does not resolve the question of the interrelation between the Czech and Polish projects of Central Europe and the question of the position from which one should look at the former. She writes that "the Czech projects of Central Europe can therefore be seen in the constant rift between the deconstruction and updating of revival narrations, between critical reflection on national identity and its idealisation, between particularism and concentration on the "Czech question" and the reflection on universal problems" (Parfianowicz-Vertun 2016: 233-234).

\footnotetext{
7 This is due to the etymology of the word (political means "related to polis"), and not to the definition. See https://plato.stanford.edu/entries/aristotle-politics/ (accessed: 21.06.2017).
} 
The thing is that these are almost always the same questions, traceable back to their first advocates - such as the above-mentioned Tomáš Garrigue Masaryk. Parfianowicz-Vertun cites Martin Kučera, who points out that "Czech culture should be studied in the dynamic tension between the two tendencies, as a synthesis of what is "national and universal, tradition and avant-garde, continuity and break-up"' (ibid.: 265). This particular tension, let me emphasise once again, results from the fact that the question of Central Europe has been interpreted in light of the debate over the meaning of Czech history (the so called "Czech question"). As Otto Urban remarked, "the Czech question [...] has become a complex of all the problems whose common denominator was the reformist attempt to democratise society" (Urban 1982: 443). For the intellectual circles of the 1970s and 1980s, described by Parfianowicz-Vertun, the "Czech question" was sometimes interpreted as a compensatory ideology of post-1968 disillusionment, a means of coming to terms with the recent past (Havelka 2001: 160).

My criticism of Parfianowicz-Vertun's book is partly due to the fact that the author's conclusions are not consistent. She writes that for the Czechs,

the question about Central Europe is in fact a pretext to reflect on the Czech national identity and cultural heritage (ParfianowiczVertun 2016: 139);

[and also that] when...Czechs discuss Central Europe, among other things they speak about the traditions of the Czech National Revival, and in two ways. First, they refer to the point at which the image of being central on the map of Europe became an essential element in the narrative about the character, role, and mission of the Czech people, and second, discussions of the late twentieth century became a pretext for another (successive in the following years) revision of various myths and ideas associated with the development of modern Czech identity (Parfianowicz-Vertun 2016: 207).

However, the question of Central Europe (and the place of Czech culture in it) is not linked in the book to the question of the meaning of Czech history: a question related to Slavic culture as such, concerning the extent to which the meaning of history can combine visions of the future with assumptions about the origin of a culture (Havelka 2001: 51). It is there- 
fore plausible to return to the period of the Czech National Revival and to ask how much the question of Central Europe can be connected with it. Parfianowicz-Vertun gives numerous reasons for a reflective return to this period in Czech history, including in the texts and practices she describes, because she notes, for example, that samizdat grew out of the tradition of nineteenth-century national liberation activities (Parfianowicz-Vertun 2016: 73). However, she makes little use of these observations in further analysis. This is also the case in texts that question the ties between Czech culture and Western European tradition (ibid.: 227).

The main question that arises at this point is whether we can simply analyse essays from the 1970s and 1980s, where the meaning of Czech history is a central concept, without any reflection on long-term historical processes. "Czech projects of Central Europe rarely problematise the difficult neighbourhood and the conflicts that haunt this area," writes ParfianowiczVertun (2016: 231). A careful student of Czech culture might be tempted to raise an objection here as well: for example, what about František Palacký's idea of the Czech-German stýkáni a potykání [contact and conflict]. According to Palacký, the constant contact between Czech and German cultures led to their mutual enrichment, even if at times it deepened conflicts or threats "enriching" the military forces, political ambitions, and cultural exclusiveness.

The discussions about Central Europe are also similar to the debates on the "Czech question" in that that they make it possible to trace the clash of ideals (considerations on the political future) with practice. The "Czech question" should be confronted with the reality of the First Republic of Czechoslovakia (1918-1938), and projects of Central Europe with the years after the turning point of 1989. Parfianowicz-Vertun borrows the concept of the relation between ideas and political practice from Krzywicki, and treats Central Europe as a task. The issues raised by Palacký can also be found in the question of Czech nationalism, which is mentioned by Parfianowicz-Vertun (2016: 273). Among other questions, she asks here about the use of the Holocaust in Czech discourse and its unresolved experience - the Czechs have not yet come to terms with it - while she does not address the "German question." The expulsion of about 3 million of Czech Germans after 1945 ended a certain stage in discussion of the "Czech question" (closing the era of stýkáni a potykáni), but in the period analysed by Parfianowicz-Vertun there was discussion among Czech historians on the sense and price of the forced displacements. The articles, collected after the revolution in the volume Češi, Némci, odsun. Diskuse neáavislých historikè 
(Černý 1990) show a different view of the "Czech question," where the issue of Czech nationalism - including the nationalism contemporary to the authors - is central. Parfianowicz-Vertun emphasises that

by following the biographies of intellectuals engaged in the discussion of Central Europe, we can see [...] that many of them shared an ambivalent attitude toward their own national cultures. The "Central European" project was for many of them an attempt to overcome the limitations of a narrowly defined national community. This was one of the reasons why they were so eager to refer to Central European mythology, especially the one associated with the microcosm of Vienna and Prague at the turn of the centuries (Parfianowicz-Vertun 2016: 383).

This ambiguity about one's own culture was not connected solely with the conservative nature of the unofficial culture but also with the reopening of the discussion over Czech culture as syncretic, co-created for centuries by Czechs and Germans, and thus bridging the imagined boundaries of the national. Two classical ideas of "being Czech" account for this tension: Josef Jungmann's project that linked it with language, and the one by Bernard Bolzano, who emphasised the importance of living on the territory of the Czech lands. These two types of "being Czech," tschechich and bömisch, were echoed after the revolution as well, and more recently were playfully recalled by Bohumil Hrabal in one of his late silva rerum (Hrabal 2005).

\section{/// Where Are You, Central Europe?}

Apart from the connections between the questions of Central Europe and the meaning of Czech history, I would like to draw attention to the most interesting part of Parfianowicz-Vertun's book. The core of the book is constituted by a rich, theoretically-informed empirical analysis; the purely theoretical considerations presented in chapter 2 deserve attention as well. Parfianowicz-Vertun calls attention not only to the process of reconstructing texts, but also to the problem of how they circulated: (a) in purely academic publications; (b) in cultural and social journals addressed to the general public; and (c) in unofficial publications. The study of these texts is clearly a methodological challenge. The same texts were frequently reprinted in different versions by different editors. They were directed at 
various audiences, on both sides of the Iron Curtain. Finally, it was not solely a text's content but also accident that influenced its readership. Therefore, as Parfianowicz-Vertun notes, the canon of texts about Central Europe is made up mainly of those texts that were published in the West (2016: 70) and not anonymously (ibid.: 112-115) - this was a problem for texts published in Czechoslovakia, Poland, and Hungary, where authors could be held accountable by the authorities. In addition, the reception of the texts published in the region was smaller due to factors such as those mentioned by Parfianowicz-Vertun: "the difficult, often random, selective access to particular titles; poor print quality and trouble with reading the texts; the unclear status of the authors, who were publishing anonymously or under a pseudonym; and finally the nature of the texts themselves, which often took the form of long, detailed dissertations" (ibid.: 118-119). Since production of a text involved specific "editorial" and distribution practices (such as transcription for further distribution among trusted friends and acquaintances), Parfianowicz-Vertun's suggestion that this form of informal circulation among opposition circles had a greater cultural impact than any open debate on the texts is absolutely legitimate. The processes of producing texts seem to have integrated people even more than the ideas their authors put forward (ibid.: 119).

The texto-centric character of the project of Central Europe on the eastern side of the Iron Curtain was also a result of the aesthetic assumptions adapted in samizdat, especially the focus on content, thus justifying an ugly layout (Parfianowicz-Vertun 2016: 105). We should spend some time on this "texto-centric" character: on the one hand, it means here that Central Europe exists primarily in texts, particularly essays, as the author argues. On the other hand, it might be asked whether there are some argumentative structures that are intricately related and chronologically disrupted, leading to a repetition of the blurry geographic-cultural shape of Central Europe in an out-of-shape debate itself. It should also be added that the text, as Parfianowicz-Vertun describes it, is also a material object of a certain type, printed in certain conditions, distributed in a certain way. Hence the title of the book: "w tekstach i działaniach" [in texts and actions]. Text as a physical being is also a social process here which causes a series of actions - or calls for them to take place.

It is possible, on the basis of the author's remarks, to consider whether the real space where Central Europe existed were all the barns, attics, buildings, and state printeries where unofficial newspapers were printed "after hours," and the private houses where texts were printed and tran- 
scribed, and discussions on this subject took place (Parafianowicz-Vertun 2016: 134). Central Europe then not only transcends into the area where the texts are functioning, it is not just a kind of "epistolary republic," as the milieu of the Parisian Kultura was called (ibid.: 305), but also fails to fit Barbara Toruńczyk's definition of "the area of the spiritual search" (Toruńczyk 2013: 155). It is born in real spaces as it constitutes an actual practice. Obviously enough, the milieu of this idea does not lie where its proponents tend to locate it. I regret that the author of Europa Środkowa w tekstach $i$ driataniach does not follow this interesting line of interpretation, which I find capable of shedding a new light on what had seemed to be a worn-out subject.

More importantly, Parfianowicz-Vertun brilliantly points to the irony of the project of Central Europe which on the micro-level was not "a republic" but rather "republics of friends": "Polish projects take equally minor account of Czech historical and cultural experience as the Czech ones problematise Polish specificity" (2016: 205). And thus, when viewed from the Czech perspective, Czech questions seem "central," while the Poles acquire a peripheral character as they address the question of the far away "Kresy" (ibid.: 297). Jan Patočka, while commenting on Masaryk's view of the meaning of Czech history, noted that it is typical for marginal existences to want to be in the centre. His words accurately describe the projects of Central Europe, which appear to be just a conglomerate of national debates rather than a common vision creatively reworking the cultural variety it claims to represent. Each of the national debates is a kidnapper rhetoric which dresses its own perspective in the gown of a bigger cause. Thus it also fails to find a proper place for Central Europe as part of a bigger political project of a common Europe.

Bibliography:

/// Bal M. 2002. Travelling Concepts in the Humanities: A Rough Guide, University of Toronto Press.

/// Černý B., ed. 1990. Cešri, Nèmci, odsun: Diskuse nezávislých historikư, Academia.

/// Havelka M. 2001. Déjiny a smysl, Nakladatelství Lidové noviny.

/// Hobsbawm E., Ranger T., eds. 2008. Tradycja uynaleziona, transl. M. Godyń, F. Godyń, Wydawnictwo Uniwersytetu Jagiellońskiego. 
/// Hrabal B. 2005. Różowy kawaler, transl. K. Kępka, Świat Literacki.

/// Kosík K. 1993. Století Markéty Samsové, Český spisovatel.

/// Kowalczyk A.S. 1990. Kryzys świadomości europejskiej w eseistyce polskiej 1945-1977. Vincen₹, Stempowski, Miłosz, Quantum.

/// Masaryk T.G. 1948 [1895]. Česká otázka. Snaby a tužby národníbo obrození. Naše nynèjš́ krise. Pád strany staročeské a počátkové smèrù nových, Čin.

/// Palacký F. 1900. "Stručný přehled dějin českých doby starší (až do r. 1526)," [in:] F. Palacký, Františkea Palackého Spisy drobné, II, Clánky z. oboru dĕjin, Bursik \& Kohout.

/// Parfianowicz-Vertun W. 2016. Europa Środkowa w tekstach $i$ driałaniach. Polskie i czeskie dyskusje, Wydawnictwa Uniwersytetu Warszawskiego.

/// Schauer H.G. 1886. "Naše dvě otázky," Čas, vol. 1, pp. 1-4.

/// Toruńczyk B. 2013. Z opowieści wschodnioeuropejskich, Fundacja Zeszytów Literackich.

/// Urban O. 1982. Ceská společnost 1848-1918, Svoboda.

/// Karolina Ćwiek-Rogalska - Ph.D., graduate of ethnology and Czech Studies, assistant professor at the Institute of Slavic Studies, Polish Academy of Sciences. She is interested in the displacement of German-speaking inhabitants from Czechoslovakia and Poland, the Czech National Revival, and philosophy in the nineteenth and twentieth centuries. Her most recent publications include the monograph Zapamietane w krajobrazie. Krajobraz. czesko-niemieckiego pogranicza w czasach przemian (2017) and articles in well-known journals (Przeglad Zachodni, Res Publica Nowa, Bohemia: Zeitschrift für Geschichte und Kultur der Böhmischen Länder). She is editor-in-chief of Adeptus.

Email: karolina.rogalska@ispan.waw.pl 